\title{
Temporal Variability of Cetaceans near Halifax, Nova Scotia
}

\author{
Peter Simard ${ }^{1,2}$, JenNifer L. LAWLOR ${ }^{3}$, and ShanNOn Gowans ${ }^{1,4}$ \\ ${ }^{1}$ Blind Bay Cetacean Studies, 144 Victoria Road, Dartmouth, Nova Scotia B3A 1V7 Canada \\ ${ }^{2}$ University of South Florida, College of Marine Science, $1407^{\text {th }}$ Avenue South, St. Petersburg, Florida 33701 USA; e-mail: \\ psimard@marine.usf.edu. \\ ${ }^{3}$ Department of Biology, Dalhousie University, Halifax, Nova Scotia B3H 4J1 Canada \\ ${ }^{4}$ Eckerd College, $420054^{\text {th }}$ Avenue South, St. Petersburg, Florida 33711 USA
}

Simard, Peter, Jennifer L. Lawlor, and Shannon Gowans. 2006. Temporal variability of cetaceans near Halifax, Nova Scotia. Canadian Field-Naturalist 120(1): 93-99.

Annual and seasonal trends in sightings of coastal cetaceans near Halifax, Nova Scotia, were studied using observations from whale watching and dedicated research vessels from late spring to early fall of 1996 to 2005 . Four species of cetaceans routinely used the area during the summer: White-beaked and Atlantic White-sided dolphins (Lagenorhynchus albirostris and L. acutus), Harbour Porpoises (Phocoena phocoena), and Minke Whales (Balaenoptera acutorostrata). The dolphin species were temporally separated, with White-beaked Dolphins being common earlier in the summer than White-sided Dolphins. White-sided Dolphins were unusually abundant in 1997, and were found in larger groups (mean $=46.5 \pm 46.19$ sd) than Whitebeaked Dolphins (mean $=9.1 \pm 5.19 \mathrm{SD}$ ). The area also appears to be an important habitat for dolphin calves and juveniles of both species. Fin Whales (B. physalus) were commonly observed in relatively large groups in 1997, but were uncommon or absent in other years. Humpback Whales (Megaptera novaeangliae), Blue Whales (B. musculus) and North Atlantic Right Whales (Eubalaena glacialis) were uncommon in the area, although Humpback Whales were sighted frequently in 1997. Increased numbers of White-sided Dolphins, Fin and Humpback whales in 1997 may be explained by increased prey abundance and decreased sea-surface temperatures.

Key Words: White-beaked Dolphin, Lagenorhynchus albirostris, Atlantic White-sided Dolphin, Lagenorhynchus acutus, Harbour Porpoise, Phocoena phocoena, Minke Whale, Balaenoptera acutorostrata, Fin Whale, Balaenoptera physalus, Humpback Whale, Megaptera novaeangliae, seasonality, group size, calves, Nova Scotia.

In temperate ecosystems, it is common for cetaceans to exhibit seasonal and annual fluctuations in their distribution and abundance (e.g., Hooker et al. 1999). These fluctuations are thought to be a reflection of seasonal changes in the environment, such as sea surface temperature (e.g., Hooker et al. 1999) and prey distribution (e.g., Kenney et al. 1996). Monitoring highly mobile, top level predators such as cetaceans serves not only to identify their habitat use patterns and track their population sizes, but also to monitor the health of the overall marine ecosystem.

The area between Halifax and Mahone Bay, Nova Scotia, is habitat for several species of cetaceans. It is used extensively by the commercial fishing industry, commercial shipping (especially near Halifax Harbour) and recreational boaters, and it is being used increasingly for whale watching. Given the high potential for anthropogenic influences in the Halifax area, there is good reason to study and monitor cetaceans there.

\section{Methods}

\section{Field Methods}

Data were collected from 1996 to 2005, primarily from 1 June to 30 September. From 1996 to 1999 , $12.6 \mathrm{~m}$ and $14 \mathrm{~m}$ whale watching vessels were used to make three 3-hour trips daily, weather permitting. In 2000 and 2001 , an $8.5 \mathrm{~m}$ auxiliary sailing vessel was used, and in 2002 to 2005 a 4.2 m rigid inflatable boat was used. The latter two vessels were used only for research, and cruises in 2000 to 2005 were generally conducted only in weather conditions suitable for photo-identification. All surveys were limited to daylight hours and the area bounded by approximately $44^{\circ} 19^{\prime}$ to $44^{\circ} 38^{\prime} \mathrm{N}$ latitude and $63^{\circ} 15^{\prime}$ to $64^{\circ} 10^{\prime} \mathrm{W}$ longitude (Figure 1). The path of all vessels was opportunistic, based on where cetaceans were previously sighted. In 1996, only date, time, species, group size and the presence of calves and juveniles were recorded. In subsequent years, latitude and longitude positions were recorded (using GPS) for hourly search effort and species positions and photo-identification data were collected. Only those sightings identified to species level were included in analysis.

Animals were classified as adults, juveniles or calves. For odontocetes, first year calves were identified by having a length of $<50 \%$ of adult body length, while juveniles were identified by having $50 \%-70 \%$ of adult body length (Reeves et al. 1999; Lien et al. 2001; Bjørge and Tolley 2002). The identification of calves was often facilitated by their position near an adult, with younger calves displaying "chin-slap" surfacings, and in the case of neonatal calves, by fetal folds and bent-over dorsal fins (Weinrich et al. 2001). For mysticetes, calves were identified by having a length of 
$<40 \%$, and juveniles by having a length of $40 \%-60 \%$ of adult body length (Aguilar 2002; Clapham 2002; Perrin and Brownell 2002).

Over the ten-year study period, changes in methodology introduced several biases to our data. Data collected from the whale watching boats (1996-1999) were particularly problematic as the boat returned several times per day with new passengers to the same area where cetaceans had previously been sighted, potentially causing groups to be double-sampled and introducing a positive bias to calculations of hourly sighting rates. Cetacean encounters on the whale watching vessels were typically shorter in duration, and therefore a larger proportion of time was spent searching for new groups, introducing another potentially positive bias. However, the whale watching vessels were more likely to operate in inclement weather than the research vessels, which should negatively bias the sighting data. Larger groups were preferred on whale watching cruises, positively biasing group sizes. Vessel cruising speed also varied greatly in the nine year study period (ranging from 5 to 15 knots). These differences in survey speed changed our spatial sampling greatly, and therefore likely affected the sighting data. The height of observers above the sea surface also varied greatly, from a minimum $1.25 \mathrm{~m}$ to a maximum $5 \mathrm{~m}$. Search effort varied greatly between different years and months, and as a result time periods with low effort may have had unreliable sighting rates (see Table 1a and 1b).

\section{Calculation of Sighting Indices}

Because of these biases, regular group sighting rates (sightings per hour) would not be directly comparable. Therefore, the data were restricted in order to calculate a "sighting index" for each species per year and per month. Potential positive biases from repeated sampling of the same cetaceans throughout the day were eliminated by daily scoring each species as present or absent. This restriction also reduces biases introduced from differences in vessel speed, and time spent searching vs. time spent with groups of cetaceans. Calculated sighting indices could range from a maximum of 1.0 (sightings occurring every day of field effort) to 0.0 (no sightings). In order to determine if weather significantly affected sighting rates, the sighting rates during good weather and bad weather were subjected to a chi-squared test. Good weather was defined as visibility $\geq 1 \mathrm{~km}$, wind $\leq$ Beaufort $3(\leq \approx 19 \mathrm{~km} / \mathrm{hr})$, wave height $\leq 0.75 \mathrm{~m}$, and swells $\leq 1.5 \mathrm{~m}$. Results from this test indicate that sighting rates were significantly lower in poor weather $\left(\chi^{2}=0.9999, \mathrm{df}=5\right.$, $0.025<P<0.05$ ). Therefore, in order to reduce bias due to weather conditions, only sightings during good weather were included in analysis. Consequently, the sighting index was calculated as the proportion of good weather days each species was observed, and serves as an indicator of relative abundance. Data from 1996 and 2000 were not included in the analysis, as the envi-

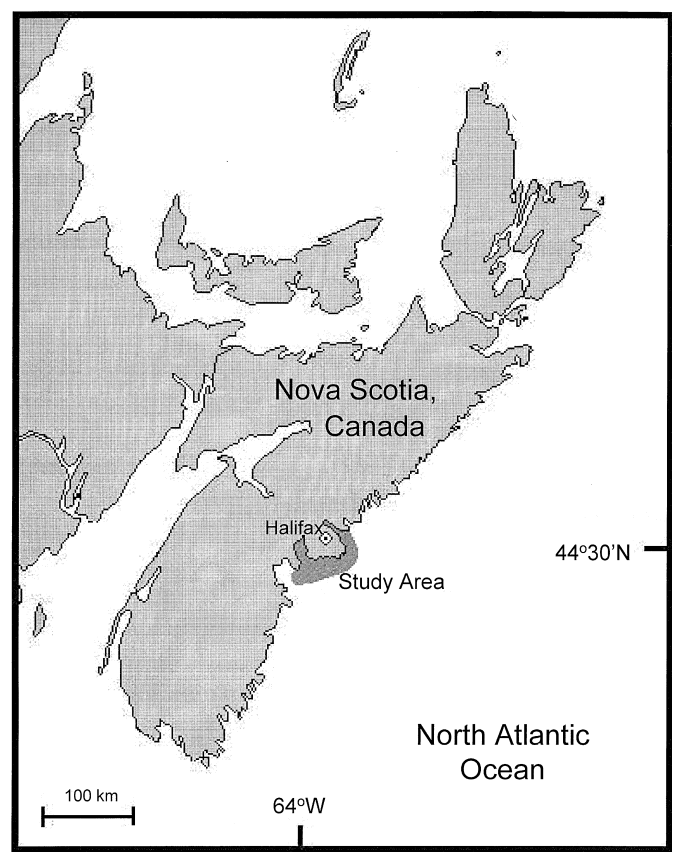

FIGURE 1. Location of study area.

ronmental data were not collected frequently enough to determine if specific sightings occurred during good weather. In addition, any year or month in which the effort was less than or equal to five days and any species with less than or equal to 10 sightings in total were omitted from analysis as results from these would likely be unreliable (Table 1).

\section{Analysis}

Chi-squared tests were used to test the null hypothesis that monthly and yearly sightings were random. Group sizes and the proportions of groups with calves, juveniles and total sub-adults (calves + juveniles) were also calculated for all species observed more than 10 times. Data were restricted to one randomly selected sighting per day in order to reduce biases caused by repeated sightings of the same group and by selection for larger groups by the whale watching vessels. In addition, these calculations were conducted only on sightings which lasted five minutes or longer, as it was difficult to accurately estimate group size and presence of sub-adults during shorter encounters. Group sizes and the proportion of groups with calves and juveniles were calculated both for all selected sightings and for selected sightings which occurred during good weather conditions. As the differences in the results of these two methods were negligible, the full data set was used for analysis of group composition and size.

\section{Results}

Between 1996 and 2005, eight species of cetaceans were sighted during 1715 hours (309 days) in the field. 
TABLE 1. Search effort and number of sightings using full data set (a) for year and (b) for month (pooled across years).

\begin{tabular}{|c|c|c|c|c|c|c|c|c|c|c|c|}
\hline \multirow{2}{*}{$\frac{\text { (a) }}{1996}$} & \multicolumn{2}{|c|}{$\begin{array}{c}\text { Effort in } \\
\text { hours } \\
\text { (days) }\end{array}$} & \multirow{2}{*}{$\begin{array}{c}\begin{array}{c}\text { White- } \\
\text { beaked } \\
\text { Dolphin }\end{array} \\
25\end{array}$} & \multirow{2}{*}{$\begin{array}{l}\text { White- } \\
\text { sided } \\
\text { Dolphin } \\
28\end{array}$} & \multirow{2}{*}{$\begin{array}{c}\text { Harbour } \\
\text { Porpoise }\end{array}$} & \multirow{2}{*}{$\begin{array}{l}\text { Minke } \\
\text { Whale }\end{array}$} & \multirow{2}{*}{$\begin{array}{c}\begin{array}{c}\text { Fin } \\
\text { Whale }\end{array} \\
0\end{array}$} & \multirow{2}{*}{$\begin{array}{c}\begin{array}{c}\text { Hump-back } \\
\text { Whale }\end{array} \\
0\end{array}$} & \multirow{2}{*}{\multicolumn{2}{|c|}{ 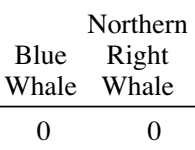 }} & \multirow{2}{*}{$\begin{array}{r}\text { Total } \\
200\end{array}$} \\
\hline & 477 & (79) & & & & & & & & & \\
\hline 1997 & 487 & (60) & 16 & 78 & 12 & 117 & 110 & 52 & 0 & 0 & 385 \\
\hline 1998 & 47 & (7) & 4 & 2 & 4 & 23 & 1 & 0 & 0 & 0 & 34 \\
\hline 1999 & 304 & (51) & 19 & 5 & 23 & 74 & 0 & 0 & 0 & 0 & 121 \\
\hline 2000 & 31 & (7) & 0 & 1 & 0 & 1 & 0 & 0 & 0 & 0 & 2 \\
\hline 2001 & 31 & (5) & 2 & 0 & 1 & 3 & 0 & 0 & 0 & 0 & 6 \\
\hline 2002 & 87 & (23) & 11 & 6 & 13 & 8 & 2 & 0 & 1 & 0 & 41 \\
\hline 2003 & 139 & (45) & 13 & 8 & 15 & 37 & 4 & 0 & 0 & 0 & 77 \\
\hline 2004 & 54 & (15) & 13 & 1 & 7 & 17 & 0 & 0 & 0 & 2 & 40 \\
\hline 2005 & 58 & $(17)$ & 5 & 1 & 13 & 6 & 0 & 1 & 1 & 0 & 27 \\
\hline Total & 1715 & (309) & 108 & 130 & 102 & 419 & 117 & 53 & 2 & 2 & 933 \\
\hline
\end{tabular}

\begin{tabular}{|c|c|c|c|c|c|c|c|c|c|c|c|}
\hline \multirow{2}{*}{$\frac{\text { (b) }}{\text { April }}$} & \multicolumn{2}{|c|}{$\begin{array}{l}\text { Effort in } \\
\text { hours } \\
\text { (days) }\end{array}$} & \multirow{2}{*}{$\begin{array}{c}\begin{array}{c}\text { White- } \\
\text { beaked } \\
\text { Dolphin }\end{array} \\
0\end{array}$} & \multirow{2}{*}{$\begin{array}{c}\begin{array}{c}\text { White- } \\
\text { sided } \\
\text { Dolphin }\end{array} \\
0\end{array}$} & \multirow{2}{*}{$\begin{array}{c}\text { Harbour } \\
\text { Porpoise } \\
1\end{array}$} & \multirow{2}{*}{$\begin{array}{c}\text { Minke } \\
\text { Whale }\end{array}$} & \multirow{2}{*}{$\begin{array}{c}\begin{array}{c}\text { Fin } \\
\text { Whale }\end{array} \\
0\end{array}$} & \multirow{2}{*}{$\begin{array}{c}\begin{array}{c}\text { Hump-back } \\
\text { Whale }\end{array} \\
0\end{array}$} & \multirow{2}{*}{\multicolumn{2}{|c|}{$\begin{array}{cc}\text { Blue } & \begin{array}{c}\text { Northern } \\
\text { right } \\
\text { Whale }\end{array} \\
\text { Whale }\end{array}$}} & \multirow{2}{*}{$\begin{array}{r}\text { Total } \\
1\end{array}$} \\
\hline & 4 & (2) & & & & & & & & & \\
\hline May & 66 & (23) & 5 & 0 & 6 & 33 & 0 & 0 & 0 & 0 & 44 \\
\hline June & 361 & (79) & 48 & 1 & 31 & 45 & 7 & 2 & 0 & 2 & 127 \\
\hline July & 544 & (87) & 44 & 34 & 39 & 93 & 33 & 12 & 1 & 0 & 242 \\
\hline August & 494 & (74) & 11 & 76 & 18 & 215 & 55 & 33 & 1 & 0 & 405 \\
\hline September & 217 & (39) & 0 & 16 & 7 & 29 & 17 & 5 & 0 & 0 & 74 \\
\hline October & 24 & (4) & 0 & 3 & 0 & 4 & 5 & 1 & 0 & 0 & 13 \\
\hline November & 5 & (1) & 0 & 0 & 0 & 0 & 0 & 0 & 0 & 0 & 0 \\
\hline Total & $\overline{1715}$ & $\overline{(309)}$ & $\overline{108}$ & $\overline{130}$ & $\overline{102}$ & $\overline{419}$ & $\overline{117}$ & 53 & 2 & 2 & $\overline{933}$ \\
\hline
\end{tabular}

White-beaked Dolphins (Lagenorhynchus albirostris), Atlantic White-sided Dolphins (L. acutus; henceforth referred to as White-sided Dolphins), Harbour Porpoises (Phocoena phocoena) and Minke Whales (Balaenoptera acutorostrata) were observed in most years although annual and seasonal variations were observed (Tables 1a and 1b). Fin Whales (B. physalus) and Humpback Whales (Megaptera novaeangliae) were observed occasionally, and Blue Whales (B. musculus) and North Atlantic Right Whales (Eubalaena glacialis) were observed only rarely (Tables $1 \mathrm{a}$ and $1 \mathrm{~b}$ ).

Annual sighting indices of White-beaked and Whitesided dolphins, Harbour Porpoises, Minke Whales, Fin Whales and Humpback Whales were significantly different from random (Table 2a). White-beaked Dolphins were sighted more frequently in 2003 and 2004 and White-sided Dolphins were sighted more frequently in 1997 and 2002. Harbour Porpoises were observed more commonly in 2002 and 2005, and Minke Whales were observed more commonly in 1999 and 2004. Fin and Humpback whales were sighted more frequently in 1997.

Monthly sightings of White-beaked and White-sided dolphins, Fin Whales and Humpback Whales were significantly different from random (Table $2 b$ ). Whitebeaked Dolphins were observed more frequently than expected early in the summer (June and July), while White-sided Dolphins were sighted more frequently than expected late in the summer (July through September). Fin Whales were observed more frequently than expected in August and September, and Humpback Whales were seen more frequently than expected in August. Monthly sightings did not differ significantly for Harbour Porpoises and Minke Whales.

White-sided Dolphins were found to have the largest mean group size of $46.5( \pm 46.19 \mathrm{SD})$, and the highest proportion of groups with calves (0.354). Harbour Porpoises had the smallest group size of the odontocetes (mean $=2.7 \pm 1.78 \mathrm{SD}$ ). . Mysticete group sizes were typically smaller than odontocetes and only a few juveniles and no calves were observed (Table 3 ).

\section{Discussion}

White-beaked and White-sided Dolphins, Harbour Porpoises and Minke Whales were found in all years in which more than seven days were spent in the field (Table 1a). This suggests that the Halifax area was an important summer habitat for these species, while Fin Whales, Humpback Whales, Blue Whales and North Atlantic Right Whales were occasional visitors. Although some significant temporal variability found in this study cannot be directly explained, several interesting trends were noticed.

\section{Annual Variation}

White-sided Dolphins were unusually abundant in 1997, along with Fin and Humpback whales (Table 
TABLE 2. Effort and number of presence/absence sightings using data set restricted as outlined in methods, (a) for year and (b) for month (pooled across years). Sighting indices (proportion of good weather days each species seen) shown in brackets. "*” indicates non-random distribution $(P<0.005)$.

\begin{tabular}{lccccccc}
\hline \hline a) & $\begin{array}{c}\text { Effort in } \\
\text { days }\end{array}$ & $\begin{array}{c}\text { White-beaked } \\
\text { Dolphin }\end{array}$ & $\begin{array}{c}\text { White-sided } \\
\text { Dolphin }\end{array}$ & $\begin{array}{c}\text { Harbour } \\
\text { Porpoise }\end{array}$ & $\begin{array}{c}\text { Minke } \\
\text { Whale }\end{array}$ & $\begin{array}{c}\text { Fin } \\
\text { Whale }\end{array}$ & $\begin{array}{c}\text { Hump-back } \\
\text { Whale }\end{array}$ \\
\hline $\mathbf{1 9 9 7}$ & 40 & $9^{*}(0.225)$ & $2^{*}(0.500)$ & $8^{*}(0.200)$ & $2^{*}(0.675)$ & $27^{*}(0.675)$ & $14^{*}(0.350)$ \\
$\mathbf{1 9 9 9}$ & 33 & $9^{*}(0.273)$ & $2^{*}(0.061)$ & $1^{*}(0.333)$ & $2^{*}(0.818)$ & $0^{*}$ & $0^{*}$ \\
$\mathbf{2 0 0 2}$ & 11 & $3^{*}(0.273)$ & $3^{*}(0.273)$ & $7^{*}(0.636)$ & $6^{*}(0.545)$ & $1^{*}(0.091)$ & $0^{*}$ \\
$\mathbf{2 0 0 3}$ & 25 & $8^{*}(0.320)$ & $2^{*}(0.080)$ & $9^{*}(0.360)$ & $1^{*}(0.560)$ & $3^{*}(0.120)$ & $0^{*}$ \\
$\mathbf{2 0 0 4}$ & 8 & $6^{*}(0.750)$ & $1^{*}(0.125)$ & $2^{*}(0.250)$ & $6^{*}(0.750)$ & $0^{*}$ & $0^{*}$ \\
$\mathbf{2 0 0 5}$ & 17 & $4^{*}(0.235)$ & $1^{*}(0.059)$ & $9^{*}(0.529)$ & $5^{*}(0.294)$ & $0^{*}$ & $1^{*}(0.059)$ \\
Total & 134 & $39(0.291)$ & $29(0.216)$ & $46(0.343)$ & $85(0.634)$ & $31(0.231)$ & $15(0.112)$ \\
\hline Chi-squared & & $\chi^{2}=0.2444$ & $\chi^{2}=0.0003$ & $\chi^{2}=0.2138$ & $\chi^{2}=0.3592$ & $\chi^{2}=1.575 \times 10^{-9}$ & $\chi^{2}=2.026 \times 10^{-5}$ \\
& & $\mathrm{df}=5$ & $\mathrm{df}=5$ & $\mathrm{df}=5$ & $\mathrm{df}=5$ & $\mathrm{df}=5$ & $\mathrm{df}=5$ \\
& $P<0.005$ & $P<0.005$ & $P<0.005$ & $P<0.005$ & $P<0.005$ & $P<0.005$ \\
\hline \hline
\end{tabular}

\begin{tabular}{|c|c|c|c|c|c|c|c|}
\hline (b) & $\begin{array}{c}\text { Effort in } \\
\text { days }\end{array}$ & $\begin{array}{c}\text { White-beaked } \\
\text { Dolphin }\end{array}$ & $\begin{array}{c}\text { White-sided } \\
\text { Dolphin }\end{array}$ & $\begin{array}{l}\text { Harbour } \\
\text { Porpoise }\end{array}$ & $\begin{array}{l}\text { Minke } \\
\text { Whale }\end{array}$ & $\begin{array}{c}\text { Fin } \\
\text { Whale }\end{array}$ & $\begin{array}{c}\text { Hump-back } \\
\text { Whale }\end{array}$ \\
\hline May & 13 & $3 *(0.231)$ & $0^{*}$ & $\begin{array}{ll}3 & (0.231)\end{array}$ & $\begin{array}{ll}11 & (0.846)\end{array}$ & $0 *$ & $0^{*}$ \\
\hline June & 39 & $20 *(0.513)$ & $0^{*}$ & $(0.385)$ & $(0.513)$ & $2 *(0.051)$ & $1 *(0.026)$ \\
\hline July & 47 & $16^{*}(0.340)$ & $11 *(0.234)$ & $(0.383)$ & $(0.553)$ & $9 *(0.191)$ & $4 *(0.085)$ \\
\hline August & 29 & $2 *(0.069)$ & $14 *(0.483)$ & $(0.276)$ & $(0.862)$ & $12 *(0.414)$ & $9 *(0.310)$ \\
\hline September & 10 & $0 *$ & $4^{*}(0.400)$ & $(0.300)$ & $(0.600)$ & $7 *(0.700)$ & $1^{*}(0.100)$ \\
\hline Total & 138 & $41 \quad(0.297)$ & $29 \quad(0.210)$ & $47 \quad(0.341)$ & $(0.638)$ & $30 \quad(0.217)$ & $15(0.109)$ \\
\hline Chi-squarec & & $\begin{array}{l}\chi^{2}=0.0055 \\
\mathrm{df}=4 \\
P<0.005\end{array}$ & $\begin{array}{l}\chi^{2}=0.0001 \\
\mathrm{df}=4 \\
P<0.005\end{array}$ & $\begin{array}{l}\chi^{2}=0.8553 \\
\mathrm{df}=4 \\
0.05<P<0.1\end{array}$ & $\begin{array}{l}\chi^{2}=0.3220 \\
\mathrm{df}=4 \\
0.01<P<0.025\end{array}$ & $\begin{array}{l}\chi^{2}=8.837 \times 10^{-5} \\
\mathrm{df}=4 \\
P<0.005\end{array}$ & $\begin{array}{l}\chi^{2}=0.0047 \\
\mathrm{df}=4 \\
P<0.005\end{array}$ \\
\hline
\end{tabular}

2a). Several ecological correlates may explain the increases in these three species. Sea surface temperatures for Halifax Harbour were significantly lower in 1997 than in 1998 and 1999 (MANOVA $\mathrm{p}=0.002$ daily minimum, $P<0.001$ daily maximum; Ocean Data Inventory Database, Department of Fisheries and Oceans Canada). In addition, Coakes et al. (2005) attributed the abundance of Fin Whales in the study area to a local increase in Herring (Clupea harengus), Sandlance (Ammodytes americanus) and euphausiids (possibly Meganyctiphanes norvegica). These species are also potential prey items of Humpback Whales (Kenney et al. 1996), and White-sided Dolphins are known to prey upon Herring and Sandlance (Reeves et al. 1999). In 1997, we observed mixed feeding aggregations containing all three species, which has also been observed in the Gulf of Maine (see Kenney et al. 1996).

\section{Seasonal Variation}

The most noticeable trend in the monthly sightings was the temporal differences in the observations of White-beaked and White-sided dolphins (Table 2b). White-beaked Dolphins were seen more often than expected in early summer and were rarely observed in August. Even within the full data set, this species was not observed after August (Table 1b). This observation may be related to water temperature, as White-beaked Dolphins appear to prefer colder water (Lien et al. 2001). However, the species was less commonly ob- served in 1997 when water temperatures were lower (Table 2a). The seasonal movements of White-beaked Dolphins are not well understood. Large numbers occasionally become ice-entrapped in Newfoundland in February and March (Hai et al. 1996), they are seen further offshore on Grand Bank in May and June (Whitehead and Glass 1985), and they occur along the coast of Labrador from late June to at least August (Alling and Whitehead 1987). Since the 1970s, the species has been rare in the Gulf of Maine (Kenney et al. 1996), although several recent sightings and strandings in the Bay of Fundy (personal observation) and the southern Gulf of Maine (Waring et al. 2004) suggest a possible return of White-beaked Dolphins to these portions of their historical range. They also appear to be rare in offshore Nova Scotian waters (Hooker et al. 1999; Lucas and Hooker 2000). Although these observations suggest that the White-beaked Dolphins in our study area may winter in the Gulf of St. Lawrence and disperse into other areas in the spring, an offshore or more southerly wintering ground cannot be ruled out (Lien et al. 2001), and different populations may have different migratory patterns.

In contrast to the White-beaked Dolphins, Whitesided Dolphins appear to prefer the later part of the season; first seen in July, commonly observed in August and September, and still observed in October (Table 1b). This seasonal trend is similar to observations in 
TABLE 3. Mean group sizes and proportion of Dolphin groups with calves present and with any sub-adults present.

\begin{tabular}{|c|c|c|c|c|c|c|}
\hline & $\begin{array}{c}\text { White-beaked } \\
\text { Dolphin }\end{array}$ & $\begin{array}{l}\text { White-sided } \\
\text { Dolphin }\end{array}$ & $\begin{array}{l}\text { Harbour } \\
\text { Porpoise }\end{array}$ & $\begin{array}{l}\text { Minke } \\
\text { Whale }\end{array}$ & $\begin{array}{c}\text { Fin } \\
\text { Whale }\end{array}$ & $\begin{array}{c}\text { Humpback } \\
\text { Whale }\end{array}$ \\
\hline Group Size & 9.1 & 46.5 & 2.7 & 1.8 & 5.9 & 1.6 \\
\hline Range & $2-20$ & $5-250$ & $1-6$ & $1-4$ & $1-20$ & $1-4$ \\
\hline$n$ & 44 & 48 & 12 & 84 & 43 & 24 \\
\hline SD & 5.19 & 46.19 & 1.78 & 0.95 & 4.43 & 0.83 \\
\hline $\begin{array}{l}\text { Groups with calves } \\
\text { (and proportion) }\end{array}$ & $\begin{array}{r}7 \\
(0.159)\end{array}$ & $\begin{array}{r}17 \\
(0.354)\end{array}$ & $\begin{array}{r}2 \\
(0.167)\end{array}$ & 0 & 0 & 0 \\
\hline $\begin{array}{l}\text { Groups with juveniles } \\
\text { (and proportion) }\end{array}$ & $\begin{array}{r}13 \\
(0.295)\end{array}$ & $\begin{array}{r}5 \\
(0.104)\end{array}$ & 0 & $\begin{array}{r}2 \\
(0.025)\end{array}$ & $\begin{array}{r}1 \\
(0.023)\end{array}$ & 0 \\
\hline $\begin{array}{l}\text { Groups with any } \\
\text { sub-adult (and proportion) }\end{array}$ & $\begin{array}{r}20 \\
(0.455)\end{array}$ & $\begin{array}{r}17 \\
(0.354)\end{array}$ & $\begin{array}{r}2 \\
(0.167)\end{array}$ & $\begin{array}{r}2 \\
(0.025)\end{array}$ & $\begin{array}{r}1 \\
(0.023)\end{array}$ & 0 \\
\hline
\end{tabular}

the Gulf of St. Lawrence (Kingsley and Reeves 1998). However, in offshore areas of Nova Scotia the trend is reversed, and White-sided Dolphins are more common in the early summer (Hooker et al. 1999). This suggests a potential inshore-offshore migration for White-sided Dolphins in Nova Scotian waters. A similar migration has been suggested for the Gulf of Maine (Kenney et al. 1996). An alternate explanation is the existence of distinct coastal and offshore populations, each with its own migratory pattern, as seen in Common Bottlenose Dolphins (Tursiops truncatus; Wells and Scott 1999). However, as White-sided Dolphins are observed in April in the Gulf of Maine (Weinrich et al. 2001), the dolphins observed in our study area could also originate from further south.

The seasonal trends observed in the two dolphin species partially explain variations in annual sightings. For example, in 2000 White-beaked Dolphins were not observed (Table 1a). However, the first day of field work was not until late July, reducing the probability of observing the species that year.

In all years, temporal separation of the two dolphin species was observed, and they were rarely seen on the same day, with only one mixed group observed in the ten-year study period. Similar observations of temporal separation have been observed between Whitesided Dolphins and Short-beaked Common Dolphins (Delphinus delphis; Gowans and Whitehead 1995), and between Common Bottlenose and Dusky dolphins (Lagenorhynchus obscurus; Würsig and Würsig 1980). This temporal separation could be due to seasonal changes in environmental or ecological conditions. Over a larger time scale, changes in water temperature and preferred prey species were thought to explain an increase in White-sided Dolphin abundance and a decrease in White-beaked Dolphin abundance in the Gulf of Maine (Kenney et al. 1996). However, some overlap in feeding ecology is possible (Northridge et al. 1997), and temporal separation may be a means of reducing competition by partitioning resources (Roughgarden 1976). In this case, a competitive exclusion relationship may exist, as suggested by Kingsley and
Reeves (1998) for White-beaked and White-sided dolphin populations in the Gulf of St. Lawrence.

Fin Whales were seen more frequently than expected in August and September, while Humpback Whales were seen more frequently in August (Table 2b). These results are generally consistent with the migratory patterns of Humpback and Fin Whales (Aguilar 2002; Clapham 2002). Harbour Porpoises and Minke Whales showed no significant seasonality, suggesting that these species may be present in the study area for a longer season.

The temporal sighting patterns observed in this study were compared with stranding data from the Marine Animal Response Society of Nova Scotia (T. Wimmer, unpublished data). All species observed in this study stranded at least once in the study area between 1996 and 2004, with the exception of the rarely observed Humpback, Blue and North Atlantic Right whales. Several species that were not observed alive did strand in our study area between 1996 and 2004: Common Bottlenose Dolphin, Pygmy Sperm Whale (Kogia breviceps), Pilot Whale (likely Long-finned, Globicephala melas) and Sei Whale (B. borealis; although two Sei Whales were tentatively identified in the study area in August 1997). Most strandings occurred in July and August both within the study area and in the surrounding areas, months when cetaceans were most commonly observed at sea (Table 2b), although search effort for strandings was also highest in the summer. No strandings occurred in the study area from January to March, although search effort during these months was low. The only species that stranded in the study area late in the year (October - December) were White-sided Dolphins, Minke Whales and Fin Whales. We also observed these species at sea in the late summer and fall (Table $1 \mathrm{~b}$ and $2 \mathrm{~b}$ ). Fin and Minke Whales have also been observed at sea in the study area during the winter (personal observation).

\section{Group Sizes}

White-beaked Dolphins were commonly found in groups of 10-20 animals in the western Atlantic (Lien et al. 2001), and the observed group size in this study 
(mean $=9.1$; Table 3 ) was similar to that found in the Gulf of St. Lawrence (aerial surveys, mean $=8.65$; Kingsley and Reeves 1998). For White-sided Dolphins, the observed group size $($ mean $=46.5$; Table 3 ) was similar to that reported in the Gulf of Maine $($ mean $=52$; Weinrich et al. 2001). These group sizes were higher than those observed in the Gulf of St. Lawrence $($ mean $=8.25$; Kingsley and Reeves 1998) and in offshore areas of Nova Scotia (mean $=8.8$, Hooker et al. 1999). These observations support the idea of a seasonal migration into our study area from the Gulf of Maine, and/or ecological similarities between the two areas. However, group sizes were unusually high in 1997, and group sizes since 1997 have been smaller $($ mean $=32.3 \pm 38.96 \mathrm{SD})$, also supporting the hypothesis that feeding conditions were unusually good in 1997. Harbour Porpoise group size (mean $=2.7$, Table 3) was similar to other observations (e.g., mean = 2.42; Kingsley and Reeves 1998).

The group size found for Fin Whales (mean = 5.9; Table 3) was larger than many other studies in the western Atlantic (e.g., Gulf of St. Lawrence mean = 1.89; Kingsley and Reeves 1998, offshore Nova Scotia mean = 1.3; Hooker et al. 1999). The larger mean group size in this study may be due to the whale watching vessel having selected for larger groups. Consequently, smaller groups were likely omitted from our analysis as they often fell below the five minute threshold. A similar bias was discussed by Bérubé et al. (2001), who selected for larger groups of Fin Whales in the Gulf of St. Lawrence and found a mean group size of 5.89. Since 1997, fin whales were found in smaller groups $($ mean $=2.3 \pm 1.89 \mathrm{SD})$, as was more common in other areas, again suggesting that our observations of larger group sizes were likely linked to high prey abundance in 1997. Group sizes for Minke and Humpback whales (mean $=1.8$ and 1.6 , respectively; Table 3) were typical for these species (e.g., Kingsley and Reeves 1998).

\section{Calf and Juvenile Presence}

Calves and juveniles were commonly observed in groups of White-beaked and White-sided dolphins (Table 3), consistent with the calving seasons for these species (Reeves et al. 1999; Lien et al. 2001). Given that dolphins have long juvenile stages relative to the time spent as yearling calves, it is not unexpected that more White-beaked Dolphin groups contain juveniles than calves (Table 3). The presence of two neonatal calves (identified by bent dorsal fins) in June indicates that the area at least occasionally serves as a calving ground for this species. White-sided Dolphins had a much higher proportion of groups with calves (35.4\%). Young calves in "echelon position" were commonly seen in this species, and several calves with fetal folds have been observed in July and August. This suggests that these dolphins are in the study area for the peak of their calving season, and that the study area is an important nursery area for this species. White-sided
Dolphin calves were less common than in the Gulf of Maine, where $41.4 \%$ of all groups contained calves, and $51.5 \%$ to $56 \%$ of groups contained calves between July and September (Weinrich et al. 2001). Far fewer groups in our study area contain juveniles (10.4\%) than calves, supporting the hypothesis that juvenile White-sided Dolphins are segregated from other age classes, as suggested by Sergeant et al. (1980). Harbour Porpoise calves were observed far less frequently (16.7\%; Table 3) than in the Bay of Fundy (63\%; Gaskin and Watson 1985). This could be due in part to differences in research focus and methodology, and that our study area is more exposed, potentially making detection more difficult. Baleen whale sub-adults were rare during the study period (Table 3) and difficult to identify as the young were frequently far from adults. The scarcity of young calves of these species is consistent with their rapid body growth rates and what is known of their migration and calving patterns (Aguilar 2002; Clapham 2002; Perrin and Brownell 2002).

\section{Acknowledgments}

We thank the many people who have helped with field work, especially Lars Bejder, Amanda Coakes, Joe Lake, Luke Rendell, Hal Whitehead, Heidi Williams, and the staff and owners of Peggy's Cove Water Tours. S. G. was supported by The Natural Sciences and Engineering Research Council. The American Museum of Natural History, Canadian Wildlife Federation, Eckerd College, PADI Project AWARE, Illford Canada and Mountain Equipment Co-op Halifax supported this project. Tonya Wimmer provided access to stranding records, and Margie Hardie, Leszek Karczmarski, Hal Whitehead and Bernd Würsig provided helpful input for this manuscript. This paper was improved by the reviews of Jon Lien and two anonymous reviewers.

\section{Literature Cited}

Aguilar, A. 2002. Fin whale Balaenoptera physalus. Pages 435-438 in Encyclopedia of marine mammals. Edited by W. F. Perrin, B. Würsig, and J. G. M. Thewissen. Academic Press, San Diego, California.

Alling, A. K., and H. P. Whitehead. 1987. A preliminary study of the status of White-beaked Dolphins, Lagenorhynchus albirostris, and other small cetaceans off the coast of Labrador. Canadian Field-Naturalist 101: 131-135.

Bérubé, M., C. Berchok, and R. Sears. 2001. Observation of a male-biased sex ratio in the Gulf of St. Lawrence fin whale (Balaenoptera physalus): temporal, geographical, or group structure segregation? Marine Mammal Science 14: $371-381$

Bjørge, A., and K. A. Tolley. 2002. Harbor porpoise Phocoena phocoena. Pages 549-551 in Encyclopedia of Marine Mammals. Edited by W. F. Perrin, B. Würsig, and J. G. M. Thewissen. Academic Press, San Diego, California.

Clapham, P. J. 2002. Humpback whale Megaptera novaeangliae. Pages 589-592 in Encyclopedia of marine mammals. Edited by W. F. Perrin, B. Würsig, and J. G. M. Thewissen. Academic Press, San Diego, California. 
Coakes, A., S. Gowans, P. Simard, J. Giard, C. Vashro, and R. Sears. 2005. Photographic identification of fin whales (Balaenoptera physalus) off the Atlantic coast of Nova Scotia, Canada. Marine Mammal Science 21: 323-326.

Gaskin, D. E., and A. P. Watson. 1985. The harbour porpoise, Phocoena phocoena, in Fish Harbour, New Brunswick, Canada: occupancy, distribution and movements. Fishery Bulletin 83: 427-442.

Gowans, S., and H. Whitehead. 1995. Distribution and habitat partitioning by small odontocetes in the Gully, a submarine canyon on the Scotian Shelf. Canadian Journal of Zoology 73: 1599-1608.

Hai, D. J., J. Lien, D. Nelson, and K. Curren. 1996. A contribution to the biology of the White-beaked Dolphin, Lagenorhynchus albirostris, in waters off Newfoundland. Canadian Field-Naturalist 110: 278-287.

Hooker, S. K., H. Whitehead, and S. Gowans. 1999. Marine protected area design and the spatial and temporal distribution of cetaceans in a submarine canyon. Conservation Biology 13: 592-602.

Kenney, R. D., P. M. Payne, D. W. Heinemann, and H. E. Winn. 1996. Shifts in northeast shelf cetacean distributions relative to trends in Gulf of Maine/Georges Bank finfish abundance. Pages 169-196 in The northeast shelf ecosystem: assessment, sustainability, and management. Edited by K. Sherman, N. A. Jaworski and T. J. Smayda. Blackwell Science, Cambridge, Massachusetts.

Kingsley, M. C. S., and R. R. Reeves. 1998. Aerial surveys of cetaceans in the Gulf of St. Lawrence in 1995 and 1996. Canadian Journal of Zoology 76: 1529-1550.

Lien, J., D. Nelson, and D. J. Hai. 2001. Status of the whitebeaked dolphin, Lagenorhynchus albirostris, in Canada. Canadian Field-Naturalist 115: 118-126.

Lucas, Z. N., and S. K. Hooker. 2000. Cetacean strandings on Sable Island, Nova Scotia, 1970-1998. Canadian FieldNaturalist 114: 45-61.

Northridge, S., M. Tasker, A. Webb, K. Camphuysen, and M. Leopold. 1997. White-beaked Lagenorhynchus albirostris and Atlantic white-sided dolphin L. acutus distributions in Northwest European and US North Atlantic waters. Reports of the International Whaling Commission 47: 797-804.
Perrin, W. F., and R. L. Brownell, Jr. 2002. Minke whales Balaenoptera acutorostrata and B. bonaerensis. Pages 750-754 in Encyclopedia of Marine Mammals. Edited by W. F. Perrin, B. Würsig, and J. G. M. Thewissen. Academic Press, San Diego, California.

Reeves, R. R., C. Smeenk, R. L. Brownell Jr., and C. C. Kinze. 1999. White-sided dolphin, Lagenorhynchus acutus (Gray, 1828). Pages 31-56 in Handbook of Marine Mammals. Edited by S. Ridgway and R. Harrison. Academic Press, San Diego, California.

Roughgarden, J. 1976. Resource partitioning among competing species - a coevolutionary approach. Theoretical Population Biology 9: 388-424.

Sergeant, D. E., D. J. St. Aubin, and J. R. Geraci. 1980. Life history and Northwest Atlantic status of the Atlantic white-sided dolphin, Lagenorhynchus acutus. Cetology 37: 1-12.

Waring, G. T., R. M. Pace, J. M. Quintal, C. P. Fairfield, and K. Maze-Foley. Editors. 2004. U.S. Atlantic and Gulf of Mexico marine mammal stock assessments 2003. U.S. Department of Commerce, NOAA Technical Memorandum NMFS-NE-182. 287 pages.

Weinrich, M. T., C. R. Belt, and D. Morin. 2001. Behavior and ecology of the Atlantic white-sided dolphin (Lagenorhynchus acutus) in coastal New England waters. Marine Mammal Science 17: 231-248.

Wells, R. S., and M. D. Scott. 1999. Bottlenose dolphin Tursiops truncatus (Montagu, 1821). Pages 137-182 in Handbook of marine mammals. Edited by S. Ridgway and R. Harrison. Academic Press, San Diego, California.

Whitehead, H., and C. Glass. 1985. The significance of the Southeast Shoal of the Grand Bank to humpback whales and other cetacean species. Canadian Journal of Zoology 63: 2617-2625.

Würsig, B., and M. Würsig. 1980. Behavior and ecology of the dusky dolphin, Lagenorhynchus obscurus in the South Atlantic. Fishery Bulletin 77: 871-890.

Received 3 May 2005

Accepted 27 November 2006 